\title{
Article \\ Polycentric Environmental Governance to Achieving SDG 16: Evidence from Southeast Asia and Eastern Africa
}

\author{
Sacha Amaruzaman ${ }^{1, * \mathbb{D}}$, Do Trong Hoan ${ }^{2}$, Delia Catacutan ${ }^{3}$, Beria Leimona ${ }^{1}$ and Maimbo Malesu ${ }^{4}$ \\ 1 The World Agroforestry (ICRAF), Bogor 16001, Indonesia; L.Beria@cgiar.org \\ 2 The World Agroforestry (ICRAF), Ha Noi 124000, Vietnam; T.Do@cgiar.org \\ 3 The World Agroforestry (ICRAF), Los Baños 4031, Philippines; D.C.Catacutan@cgiar.org \\ 4 The World Agroforestry (ICRAF), Nairobi 00100, Kenya; M.MALESU@cgiar.org \\ * Correspondence: sacha.amaruzaman@gmail.com
}

Citation: Amaruzaman, S.; Trong Hoan, D.; Catacutan, D.; Leimona, B.; Malesu, M. Polycentric

Environmental Governance to

Achieving SDG 16: Evidence from Southeast Asia and Eastern Africa. Forests 2022, 13, 68. https://doi.org/ $10.3390 /$ f13010068

Academic Editor: Isabella De Meo

Received: 5 November 2021

Accepted: 25 December 2021

Published: 5 January 2022

Publisher's Note: MDPI stays neutral with regard to jurisdictional claims in published maps and institutional affiliations.

Copyright: (C) 2022 by the authors. Licensee MDPI, Basel, Switzerland. This article is an open access article distributed under the terms and conditions of the Creative Commons Attribution (CC BY) license (https:// creativecommons.org/licenses/by/ $4.0 /)$.

\begin{abstract}
Effective environmental governance is deemed essential in advancing the Sustainable Development Goals. However, environmental dimensions have no specific reference across the SDG 16 targets and indicators. In achieving SDG 16-the realization of peace, justice, and strong institution, polycentric environmental governance involving multiple actors across scales deserves thoughtful consideration. This study illustrates the potential of a polycentric approach to environmental governance in achieving SDG 16, using case studies of forest, watershed, and transboundary bushland and seascape management in Southeast Asia and Eastern Africa, namely Vietnam, Indonesia, and the Kenya-Somalia cross-border. By highlighting four key elements of polycentric governance namely, political will, legal framework, support from higher-level governance and capacity building, the case studies demonstrate that polycentric governance play a significant role in achieving three environment-relevant SDG 16 targets, yet these targets are silent about environmental governance dimensions. Since many conflicts arise from the environment and natural resources sector, we suggest that (i) polycentric environmental governance be strongly pursued to achieve SDG 16, and (ii) SDG 16 includes indicators specifically directed on polycentric environment and natural resource governance.
\end{abstract}

Keywords: SDG 16; polycentric governance; environmental governance; landscape governance; ecosystem services governance; cross-border environmental governance

\section{Introduction}

The 2030 Sustainable Development Goal (SDGs), as approved by the members of the United Nations in September 2015, is a global blueprint to achieve a better and more sustainable future by addressing various development challenges related to poverty, environmental degradation, and inequality. The SDG framework, with 17 inter-related goals, have the potential to lead to environmental sustainability since, in some ways, it integrates environmental targets into each of the goals compared to its predecessor, Millennium Development Goals [1]. However, achieving the SDGs is inherently perplexing, particularly in developing countries in Asia and Africa that often struggle to manage their natural resources, landscapes, and ecosystems, often due to natural resources contestation due underpinned by weak governance and institution, which can be addressed to SDG 16 on Peace, Justice, and Strong Institutions.

Stakeholders often contest natural resources and their use, and weak institutions and rules often result in conflict [2,3]. Global evidence suggests that conflict in natural resources and environmental management, arising from lack or absence of land and resource rights and weak governance, has led to violence and local communities' eviction [3,4]. Simultaneously, there are many examples where solid environmental governance and institutions can prevent or reverse environmental degradation, helping to achieve peace and justice through conflict resolution $[5,6]$. The empowerment of people and institutions strengthen 
the governance of natural resources. A comprehensive understanding of the connection between environmental governance and human well-being is vital for conflict prevention and the promotion of peace and justice.

In the context of SDG 16, environmental governance deserves serious attention, if peace and sustainable societies are to be achieved by 2030. Even though SDG 16 is considered as one of the non-environmental goals among the 17 SDGs [7], environmental activists argue that environmental issues permeate across SDG 16 targets and indicators [8,9]-for them, SDG 16 offers critical entry points to strengthen environmental governance and institutions at all levels; however, in contrast, environmental dimensions have no specific reference across the SDG 16 targets and indicators. The absence of environmental-related indicators in SDG 16 can lead to under-consideration of environmental aspects in peace and security, while UNEP links 40 per cent of the conflicts in the last 60 years to natural resources management.

The key to achieving SDG 16 in the environment sector depends on the capacity and political will of assorted actors at the various implementation scales to promote more inclusive and participatory resource governance [10]. In contemporary resources management, an effective natural resources governance system often operates at multiple governance levels rather than relying on single governance beyond any governmental administration [11,12]. This brings to the concept of 'polycentric governance as an alternative perspective from the simplification of resources governance and challenges the beliefs of centralised state command and control system and market mechanisms [13,14]. Polycentric governance represents a complex type of governance with semi-autonomous multiple decision making centres that are nested at the multiple-jurisdictional scales or involving special governance units that work across jurisdictions within the landscape or ecosystem boundary $[15,16]$. Polycentric governance poses a balance mode of governance to the classic environmental governance models, of centralisation and decentralisation, by fostering joint and/or collective resource management across the governance scales.

In achieving environmental sustainability, specific SDG targets aiming to strengthening environmental governance are deemed essential. This paper applies the polycentric governance as an analytical framework for analysing the governance of the environment and natural resources. Within the environmental sector, this paper demonstrates how the implementation of polycentric environmental governance supports the achievement of SDG 16 targets. Three empirical cases from Southeast Asia and Eastern Africa, specifically Vietnam, Indonesia, and Kenya-Somalia, draw lessons on the adoption of polycentric governance. Practical lessons from the ground works in those countries provide insights on the importance of polycentric governance and the necessary support from high-level governments through political will and legal frameworks that enable polycentrism in environmental governance, thus, contributing to the achievement of SDG 16.

\section{Literature Review and Conceptual Framework}

\subsection{Polycentric Governance in Natural Resources Management}

The problems in managing common-pool resources areas, such as watersheds and forests, are complex and involve linkages between and across multiple governance scales rather than relying on single governance $[12,17,18]$. Polycentric governance posits that resource governance would be more efficient if the management is shared collectively between multiple semi-autonomous centres of authorities [14,19]. A polycentric governance system is a complex, adaptive, multi-scales system beyond official formal policies and institutions, involving multiple interdependent actors in the decision-making and overlapping in their roles $[14,20,21]$. This complexity implies a deliberation of roles and responsibilities from one centre towards multiple centres. Stakeholders from the overlapping boundaries interact, set the policies and institutions, and share the standard rules for managing the resources [16,22].

A polycentric approach would result in more efficient governance, as decision-making and implementation of actions are done at the scales where the users are based, and the 
problems occur [12]. Together, the actors within polycentric governance from various spatial and hierarchical scales interact to co-produce the rules, norms, and regulations to manage the resources $[23,24]$. The multi-scale interactions in polycentric governance could promote social learning between actors [24,25], and contribute to a more nuanced understanding of the local needs, norms, and interests of the resource users, which can facilitate conflict resolution and help to achieve peace and justice $[5,14,26]$.

Recent studies on polycentric governance focus on natural resources management overlapping administrative boundaries, mainly water and forest resources and ecosystem services (see Table 1). Some use the polycentric framework to elaborate water management in Southeast and East Asia [27,28], Middle East [17], Latin America [29,30], and Africa [22,31-33]. Others also use the polycentric approach to discuss forest resources and ecosystem services governance around the globe, such as in Asia [34-36], Latin America [20], and Africa [37-39]. Recent studies have also addressed how the multi-scalar and multi-places governance that is similar to polycentric governance mechanism can address the governance complexity in managing and providing ecosystem services [28,40,41].

Many studies have identified the potential contribution of polycentric governance to conflict resolution. For example, establishing a multistakeholder river committee in Tanzania [32] and the informal water governance institutions in Southeast Asia [27] contributed to lessening water resource disputes. In Kenya, the new irrigation management reform improved the conflict settlement mechanism between water users and the state's Water Authority [31,33]. These studies indicate that polycentric governance helps strengthen environmental institutions by providing an interaction arena for various stakeholders from various environmental management scales.

\subsection{Environmental Governance in SDG 16}

Sustainable Development Goal 16 on peace, justice, and strong institutions embodies ten (10) targets and 23 indicators. Various opinion emerged about the scope of SDG 16 concerning environmental goals. Some scholars observed that SDG 16 is mainly about peace and justice, emphasising the rule of law and institutions to support transformative pathways to sustainability $[42,43]$. Reflecting on the scope of SDG 16 indicators and its induction background, the scholars argued that environmental dimensions, particularly environmental justice, are excluded in SDG 16 [3,8]. They highlight, for example, that the targets do not capture land rights and community participation in environmental management. Nonetheless, they agree that SDG 16 provides essential means to achieve all other SDGs [6]. In contrast, environmental advocates believe that SDG 16 has a robust environmental dimension and deem most SDG 16 targets essential to support conservation $[3,9,44]$.

Table 1. Sustainable Development Goal 16 Targets potentially linked to the environment sector.

\begin{tabular}{ccc}
\hline SDG 16 Target & Elder and Olsen [43] & UNEP [6] \\
\hline $\begin{array}{c}\text { 16.3 Rule of Law and Justice for All } \\
\text { institution at all levels }\end{array}$ & $\mathrm{V}$ & $\mathrm{V}$ \\
\hline $\begin{array}{c}\text { 16.6 Effective, accountable, and transparent } \\
\text { 16.7 Ensure responsive, inclusive, participatory, } \\
\text { and representative decision-making at all levels }\end{array}$ & $\mathrm{V}$ & $\mathrm{V}$ \\
\hline $\begin{array}{l}\text { 16.8 Broaden and strengthen the participation of } \\
\text { developing countries in the institutions of } \\
\text { global governance }\end{array}$ & $\mathrm{V}$ & $\mathrm{V}$ \\
\hline $\begin{array}{l}\text { 16.10 Ensure public access to information and } \\
\text { protect fundamental freedoms following national } \\
\text { legislation and international agreements }\end{array}$ & - & $\mathrm{V}$ \\
\hline $\begin{array}{l}\text { 16.B Promote and enforce non-discriminatory laws } \\
\text { and policies for sustainable development }\end{array}$ & $\mathrm{V}$ & $\mathrm{V}$ \\
\hline
\end{tabular}


Both scholars and environmental advocates, however, believe that the key to achieving SDG 16 lies in place-based implementation that requires contextualisation, whether at the national, sub-national, and local level [44,45]. Implementation of SDG 16 requires attention to how Government and other actors use power dynamics and interpret the SDGs according to the more significant governance trends and complex local characteristics. The achievement of SDG 16 would require greater acknowledgement of non-government actors and institutions at multiple scales and adjust governance approaches to sub-national and local contexts [10].

Significant perspectives on SDG 16 agree that the indicators are not explicit on environment-related issues [3,6], while only 6 out of 23 indicators are considered conceptually straightforward, with an established methodology [46]. For example, the indicators for SDG 16.6 on institutions, do not measure the mechanisms that foster strong institutions, while Target SDG 16.3 on law and justice do not indicate the measurement of justice. United Nations Environment Programme (UNEP) [47] stated that at least five SDG 16 targets are linked to the environment, namely targets $16.3,16.6,16.7,16.8,16.10$, and 16.B; while only four SDG 16 targets are vital for environmental management [37], namely targets 16.3, 16.6, 16.7, and 16.10 (Table 1).

Effective governance is deemed essential in advancing the Sustainable Development Goals, but the importance of polycentric governance to support SDG implementation on multiple scales has just been gradually recognised [48]. Looking at each SDG as public good and how complex the scales and stakeholders are, Goegele [15] proposes a polycentric system to governing the implementation of SDGs. The SDG Agenda requires innovative governance that embraces collaborative governance forms, and polycentric governance can provide efficient governance through its decentralised and inclusive process. Many environment-related goals are more likely to be diluted or not represented in SDG 16 indicators and easily overlook anything to do with the environment [3,6]. Polycentric environmental governance could be an entry point for governments and development actors to promote good governance and strong institutions at all levels, which is central to achieving SDG 16.

We acknowledge that there are extensive discussions on the scope of environmental governance $[49,50]$. In this paper, we address environmental governance as the convergence of the sets of regulatory processes, mechanisms, and institutions in which various actors influence the actions and outcomes of the natural resources, landscape, and ecosystem services management $[41,49]$.

\subsection{Gaps in the Literature}

From the polycentric governance and environment-related SDG 16 literature, this paper attempts to highlight some gaps and illustrate through three case studies how the application of polycentric environmental governance contributes to the attainment of SDG 16.

First, empirical studies that explore how actors acquire capacity and balance their roles in vertical and horizontal linkages within polycentric governance settings, such as through multistakeholder platforms, are scarce. Results from recent studies indicate the need to understand how the collaborative process and networks involving different actors would generate sustainable solutions to address environmental problems in socio-ecological system spanning landscape and administrative boundary [51,52]. It is crucial to understand such nuanced process in various cases, as the actors involved in relatively successful polycentric governance will constantly need to balance their roles and connections within the scales, acquire the capacity to self-govern and be actively involved in the decisionmaking process [22,35].

Second, case studies on transboundary polycentric governance are still relatively limited, as shown in the literature review. Some of the notable ones such as Schoon [53] that looked at the institutional setting of two transboundary national parks in Southern Africa, and Chen [54] in the South China Sea where they noted that transboundary water resources 
would benefit from engagement and learning between regional and local actors. Such transboundary case studies will help improve understanding of natural resource governance processes that involve different countries. The number of studies that specifically discuss transboundary polycentric governance, however, is still limited.

Third, studies that explore how strong environmental governance and institutions are developed and interlinked with SDG 16 is limited. McDermott et al. [10] provide case studies on the link between forest governance and SDG 16, but the discussion on polycentric governance and SDG 16 is scanty. It is essential to provide empirical studies on polycentric governance, as Goegele [15] suggested, to understand how polycentric systems support SDG implementation. For SDG 16, such a study is beneficial to demonstrate how polycentric environmental governance can support realization of peace, justice, and strong institutions through inclusive, participatory, and collaborative processes.

\subsection{Conceptual Framework}

We applied polycentric environmental governance and SDG16 as analytical frameworks. The SDG 16 highlights the importance of institutions to achieve sustainable development. This goal was proposed into the SDGs to cover global concerns about "governance" and "peaceful societies" not explicitly addressed in its predecessor goals, the Millennium Development Goals. The concept of governance and peaceful societies later evolved into concepts of "peace, justice, and institutions", which are to address issues regarding "rule of law", "access to justice", and "corruption". Within SDG 16, there is ample room to strengthen environmental institutions since its conception background has shown a large portion of the discussion still focusing on peace and justice [55].

SDG 16 implementation has been facing several significant challenges to sufficient progress, such as the lack of political will and leadership, insufficient financing, inadequate human resource capacity, and insufficient delivery system [5]. We identify four elements that highly contribute to strong and inclusive institutions within polycentric resource governance, relevant to achieving the targets SDG 16: political will; legal framework; support from higher-level Government; and capacity building.

First, a polycentric approach requires strong political will from actors, whether state or nongovernment, to share responsibilities and co-manage the resources. Polycentric governance implies deliberation of roles and responsibilities towards multiple governance centres, in which actors from overlapping boundaries interact and co-produce standard rules and norms for managing the resources [16,22]. Such a process requires the presence of leaders and champions who are willing to promote collaborative efforts, strategically weave the networks, and disseminate new perspectives about the potential advantages of collaboration in managing shared resources [29].

Second, polycentric governance requires enabling framework to allow a broad range of local participation. Such a framework can be in the form of formal regulations or membership in the official networking platform that encourage and allow actors to contribute to and participate in resource governance [22]. Several cases show that the lack of legal framework at a larger scale hinders effective polycentric water governance [27,36].

Third, polycentric governance requires support and acknowledgement from higher-level Government. From a national resource governance perspective, polycentric governance does not always imply a total absence of the national Government. To some extent, technical and legal support and recognition from higher-level Government are necessary to support local institutions. In Kenya, Baldwin et al. [22] found that local governance units are essential to support polycentric governance, but higher-level Government's technical and financial support help strengthen the governance.

The fourth element is capacity building for local actors involved in governance. Actors within the polycentric governance will need to balance their roles and connections between vertical and horizontal linkages and acquire the capacity to self-govern [56]. The process towards understanding and balancing the roles at multiple scales will demand specific capacity building for the actors to enable their involvement in governance and decision-making 
at the multiple scales [57]. Whereas building institutions that support local needs while conserving essential resources is essential, there is also a need to strengthen the ability of local communities to actively participate in environmental decisions that impact their lives $[29,58]$.

Polycentric governance requires strong institutions that are accountable, transparent, representative, participative, and transparent throughout the process. It is a complex, multi-scale system that operates beyond formal policies, administrative boundary, and institutions. These requirements coincide with what ought to be the processes and elements necessary to achieve just and firm institutions, through ensuring justice for all (SDG 16.3), effective, transparent, and accountable institutions (SDG 16.6), and inclusive and participatory decision making (SDG 16.7). This study focuses on these three SDG 16 targets directly related to institutions discussing their polycentric governance links. The other targets (SDG 16.8, SDG 16.10, and SDG 16.B) are considered less relevant and too broad for our case studies, as they were either targeting a very broad governance and policy scale, namely SDG 16.8 (Global Governance), SDG 16.10 (National to global governance), and SDG 16.B (non-discriminatory laws and policies).

Table 2 maps the four polycentric governance elements relevant to selected SDG 16 targets.

Table 2. Overlaps between SDG 16 and Polycentric Governance Characteristics.

\begin{tabular}{|c|c|c|c|c|}
\hline \multirow[b]{2}{*}{ SDG 16 Targets } & \multicolumn{4}{|c|}{ Polycentric Governance Characteristics/Elements } \\
\hline & Political Will & Legal Framework & $\begin{array}{l}\text { Support from Higher-Level } \\
\text { Government }\end{array}$ & $\begin{array}{l}\text { Capacity Building } \\
\text { for Local Actors }\end{array}$ \\
\hline $\begin{array}{l}\text { 16.3 Promote the rule of } \\
\text { law at the national and } \\
\text { international levels and } \\
\text { ensure equal access to } \\
\text { justice for all }\end{array}$ & Required & Highly required & Highly required & Required \\
\hline $\begin{array}{l}\text { 16.6 Develop effective, } \\
\text { accountable, and } \\
\text { transparent institutions at } \\
\text { all levels }\end{array}$ & $\begin{array}{l}\text { Central Government } \\
\text { shares authority and } \\
\text { responsibility with } \\
\text { the Local } \\
\text { Government and } \\
\text { other related } \\
\text { institutions }\end{array}$ & Required & $\begin{array}{l}\text { Highly required through } \\
\text { legal, technical, financial } \\
\text { means }\end{array}$ & $\begin{array}{c}\text { Required } \\
\text { depending on local } \\
\text { needs }\end{array}$ \\
\hline $\begin{array}{c}\text { 16.7 Ensure responsive, } \\
\text { inclusive, participatory, } \\
\text { and representative } \\
\text { decision-making at all } \\
\text { levels }\end{array}$ & $\begin{array}{l}\text { Central and Local } \\
\text { Government share } \\
\text { roles in } \\
\text { co-management and } \\
\text { co-regulation of } \\
\text { resources with other } \\
\text { institutions. }\end{array}$ & $\begin{array}{l}\text { Required, although } \\
\text { not essential in } \\
\text { some cases }\end{array}$ & $\begin{array}{l}\text { Required through legal and } \\
\text { technical support }\end{array}$ & $\begin{array}{c}\text { Required, but also } \\
\text { depends on local } \\
\text { needs }\end{array}$ \\
\hline $\begin{array}{l}\text { 16.8 Broaden and } \\
\text { strengthen the } \\
\text { participation of developing } \\
\text { countries in the institutions } \\
\text { of global governance * }\end{array}$ & $\begin{array}{l}\text { Required, at the } \\
\text { global level }\end{array}$ & $\begin{array}{l}\text { Required, at the } \\
\text { global level }\end{array}$ & $\begin{array}{l}\text { Required through legal and } \\
\text { technical support at the } \\
\text { global level }\end{array}$ & $\begin{array}{l}\text { Required, } \\
\text { depending on } \\
\text { country needs }\end{array}$ \\
\hline $\begin{array}{l}\text { 16.10 Ensure public access } \\
\text { to information and protect } \\
\text { fundamental freedoms, } \\
\text { following national } \\
\text { legislation and } \\
\text { international agreements * }\end{array}$ & Required & Required & Required & $\begin{array}{l}\text { Required, but also } \\
\text { depends on the } \\
\text { local needs }\end{array}$ \\
\hline
\end{tabular}


Table 2. Cont.

\begin{tabular}{|c|c|c|c|c|}
\hline \multirow[b]{2}{*}{ SDG 16 Targets } & \multicolumn{4}{|c|}{ Polycentric Governance Characteristics/Elements } \\
\hline & Political Will & Legal Framework & $\begin{array}{l}\text { Support from Higher-Level } \\
\text { Government }\end{array}$ & $\begin{array}{l}\text { Capacity Building } \\
\text { for Local Actors }\end{array}$ \\
\hline $\begin{array}{c}\text { 16.B Promote and enforce } \\
\text { non-discriminatory laws } \\
\text { and policies for sustainable } \\
\text { development * }\end{array}$ & Required & Required & Required & $\begin{array}{l}\text { Required, depends } \\
\text { on the local needs }\end{array}$ \\
\hline
\end{tabular}

* The potentially linked SDG 16 targets as suggested by $[43,46]$ were not applicable to our case studies.

\section{Methodology and Case Studies}

This study is based on the ground works of the authors in the global south countries. First, the study used peer-reviewed articles on polycentric governance and SDG 16 as well as grey literature, such as such as project reports, policy briefs, and working papers. For peer-reviewed articles, we reviewed 27 case studies on polycentric approaches to environmental governance. Six studies discussed polycentric governance in Latin America and 11 and 10 in African and Asian countries, respectively. More than half of these case studies (14 articles) focused on water and irrigation governance and ten on forest and REDD+ governance. Only one case study discussed fisheries governance, while two articles discussed polycentric governance for natural resources management in general. From these articles, only three articles discussed polycentric approach in transboundary environmental governance, with two articles focused on water management and an article on the global REDD+ institution.

Second, the study involved case studies undertaken in northwest Vietnam, northeast Kenya-south Somalia border, and Cidanau Watershed in the western part of Indonesia (Figure 1). The authors were directly involved in various phases of the case studies. The case studies were chosen as part of the authors' study on "governance of shared landscapes" under the global research program: Policies, Institutions, and Markets (PIM) of the Consultative Group on International Agricultural Research (CGIAR), coordinated by the International Food Policy Research Institute (IFPRI). The three case studies illustrate different scales and diversity of issues addressed through polycentric governance (Table 3). Table 3 shows the key characteristics of each study site with details described further below.

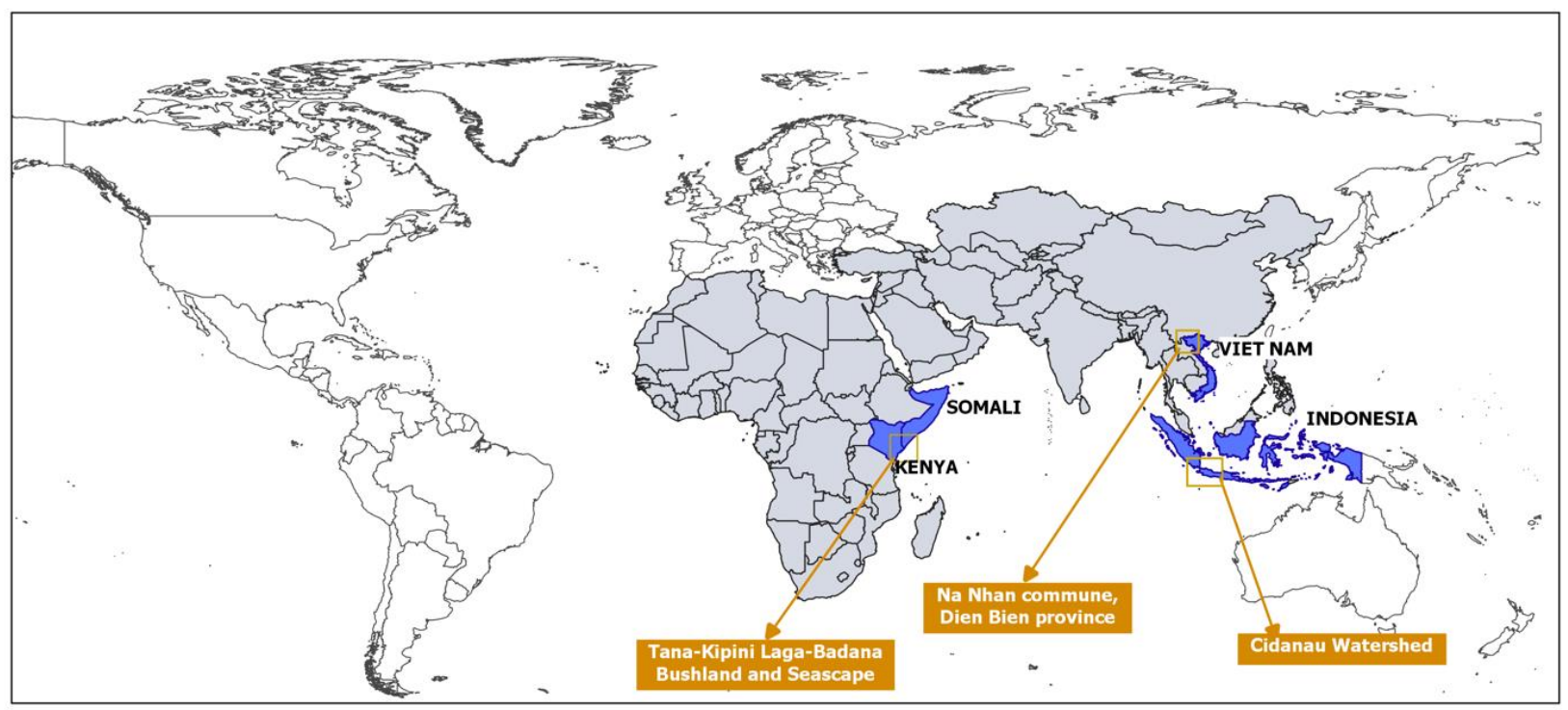

Figure 1. Case study sites in Southeast Asia and Eastern Africa. 
Table 3. Study site characteristics.

\begin{tabular}{|c|c|c|c|}
\hline Study Site & Northwest Vietnam & Kenya-Somalia & Cidanau, Indonesia \\
\hline Landscape & $\begin{array}{l}\text { Upland catchment of } \\
\text { NamRon river }\end{array}$ & $\begin{array}{l}\text { Bush Land and } \\
\text { Seascape }\end{array}$ & CWatershed \\
\hline $\begin{array}{l}\text { Dominant land } \\
\text { use }\end{array}$ & Forest + agriculture & $\begin{array}{l}\text { Protected biodiversity } \\
\text { corridor, forest, } \\
\text { grazing land }\end{array}$ & $\begin{array}{c}\text { Protected natural reserve } \\
\text { area + Agriculture } \\
\text { (agroforest) }\end{array}$ \\
\hline $\begin{array}{l}\text { Governance } \\
\text { system }\end{array}$ & $\begin{array}{c}\text { Centralised } \\
\text { (represented by } \\
\text { Commune People } \\
\text { Committee, one level } \\
\text { above the village) }\end{array}$ & Decentralised & $\begin{array}{l}\text { Decentralised to } \\
\text { district/city and the } \\
\text { village level. The } \\
\text { Provincial Government is } \\
\text { the representative of the } \\
\text { Central Government }\end{array}$ \\
\hline Governance level & $\begin{array}{l}\text { Na Nhan Commune } \\
\text { of Dien Bien Province }\end{array}$ & $\begin{array}{c}\text { Cross-border area } \\
\text { (Northeast Kenya and } \\
\text { South Somalia) }\end{array}$ & $\begin{array}{c}\text { Cilegon City, Serang } \\
\text { District and Pandeglang } \\
\text { District of Banten } \\
\text { Province }\end{array}$ \\
\hline Area size (ha) & 7600 & $2,000,000$ & 26,000 \\
\hline Issues/challenges & $\begin{array}{l}\text { Contested use of } \\
\text { forest land, forest } \\
\text { degradation, } \\
\text { inequitable payment } \\
\text { of forest ecosystem } \\
\text { services }\end{array}$ & $\begin{array}{c}\text { Resource use and } \\
\text { human conflict, } \\
\text { unclear tenure, } \\
\text { biodiversity loss, land } \\
\text { degradation, lack of } \\
\text { livelihood } \\
\text { opportunities }\end{array}$ & $\begin{array}{c}\text { Upstream: Agroforest } \\
\text { conversion; deforestation; } \\
\text { poverty } \\
\text { Downstream: } \\
\text { Sedimentation; reduced } \\
\text { water supply }\end{array}$ \\
\hline $\begin{array}{l}\text { Sustainable } \\
\text { management } \\
\text { goal/response }\end{array}$ & $\begin{array}{l}\text { Payment for forest } \\
\text { ecosystem services, } \\
\text { land use planning }\end{array}$ & $\begin{array}{l}\text { Land use planning, } \\
\text { economic } \\
\text { development } \\
\text { planning, the } \\
\text { establishment of } \\
\text { protected area } \\
\text { network }\end{array}$ & $\begin{array}{l}\text { Integrated watershed } \\
\text { management, Payment } \\
\text { for ecosystem services }\end{array}$ \\
\hline
\end{tabular}

\subsection{Cidanau Watershed, Indonesia}

Cidanau watershed covers a 22,620-hectares in two districts, Serang and Pandeglang, in the Banten Province of Java, Indonesia. In Cidanau lies the Rawa Danau Natural Reserve- the only mountainous swamp-forest ecosystem in Java that serves as the watershed's natural reservoir. The watershed plays an important role being the main water source for Cilegon, an industrial city located downstream. Krakatau Tirta Industri (KTI,) a state-owned water management company channels the water from Cidanau River to 120 essential industries in the city of Cilegon.

The remnant forest upstream of Cidanau watershed has been converted into agriculture, negatively impacting water users downstream. Upstream agricultural practices contribute to dwindling water supply. Poverty has been identified as the underlying factor of watershed degradation since low-income farmers highly depend on natural resource extraction. This has led to sedimentation, erosion and reduced water supply and quality in the watershed. The impacts of initial conservation efforts in the Cidanau watershed were insignificant and short-lived.

In the late 1990s, Rekonvasi Bhumi, a local Non-Government Organization (NGO), then mobilised local stakeholders to establish Forum Komunikasi DAS Cidanau or FKDC (Cidanau Watershed Communication Forum), a multistakeholder platform to facilitate government and non-state actors' cooperation toward integrated watershed management. FKDC initiated one of the first and longest Payments for Ecosystem Services (PES) program in Indonesia, starting in 2004, involving upstream farmers to maintain their agroforestry. The PES in Cidanau has reached its fourth implementation phase, involving upstream 
farmers as the ecosystem services (ES) providers, industries as the ES buyers (KTI and other companies in Cilegon), and the local government (Banten Province, Serang and Cilegon districts) as co-investors of the PES scheme [59].

\subsection{Na Nhan Commune, Dien Bien Province, Northwest Vietnam}

$\mathrm{Na}$ Nhan Commune, located in Dien Province of the Northwest Vietnam, is a mosaic landscape comprising natural forest on hilltops, degraded forest, grasslands; swidden plots in the midstream; and rice cultivation and settlement in the lowlands. The commune is part of a sub-catchment that feeds into a larger catchment (about $300 \mathrm{ha}$ ) upstream of the Nam Ron river that runs from northwest Vietnam to Laos PDR. Na Nhan Commune is considered one of the most degraded sub-catchments within Nam Ron Catchment, dominated by annual upland crops and bare lands while only having a small forest area. The area is continuously under extensive long-fallow rotation cultivation of annual crops. This situation contributes to the degradation of the catchment and its forest area, contested use of forestlands with agriculture, and low agricultural productivity and food security.

In the centralised government system of Vietnam, a commune is the smallest official administrative unit. The Na Nhan Commune's People Committee (Na Nhan CPC) is responsible for developing and implementing the Commune's socio-economic development plan. The Central Government manages forestlands through the provincial Forest Protection Departments. At province and district levels, local people's participation in land use and forest planning process is inadequate, if not lacking. A land-use plan is being developed every five years with details only at the commune level. A recent survey in the Commune revealed that forest law enforcement is considered less effective, and legal documents do not clearly articulate forest owners' responsibilities [60]. According to results of a focus group discussion with the village leaders in $\mathrm{Na}$ Nhan Commune, occasional forest patrolling by local authorities was not sufficient to stop forest conversion by farmers who had less rights over forest resources than those with rights to lands within the forest.

In 2008, a foreign-funded project helped establish a Community Forest Management (CFM) system on a 220-ha forestland in the commune. In 2013, about 148 ha of this community forest became part of the national Payment for Forest Ecosystem Services (PFES) programme. More recently, participatory and collaborative mechanisms to improve forest landscape governance have been tested in Na Nhan Commune by researchers from the World Agroforestry (ICRAF) and Vietnamese Academy of Forest Science (VAFS). Researchers conducted a series of local consultation meetings to develop an integrated landuse strategy to improve Na Nhan's landscape and forge shared understanding and create a common vision among Na Nhan Commune, Dien Bien Province, and District (central Government) stakeholders. This resulted in the development of Na Nhan Commune's Land Use Plan for Multiple Ecosystem Services that integrates central government laws with local values and perspectives [61].

\subsection{Tana-Kipini-Laga Badana Bush Land and Seascape, Kenya-Somalia}

The Tana-Kipini-Laga Badana Bush (TKLBB) Land and Seascape is a cross-border area between northeast Kenya and southeast Somalia. TKLBB covers 20,286 km², and is one of the 35 global biodiversity hotspots recognised by Conservation International, consisting of $17,179 \mathrm{~km}^{2}(85 \%)$ of land and seascape in Kenya, and $3107 \mathrm{~km}^{2}(15 \%)$ in Somalia. The area is underdeveloped with high poverty incidence, causing increased human pressure on the landscape's natural resources, biodiversity, and ecosystem services. Land tenure is a critical and complex issue in TLKBB. In Kenya, the establishment of settlement schemes that benefitted immigrants and favoured outsiders over locals has deepened tenure insecurity among native people deemed "squatters" by the Government [62]. Privatisation of land in the river floodplain for irrigated cropping has limited access to pastoralists and their livestock who used the floodplain as a dry season grazing refuge, which sharpens the conflict between pastoralists and farmers over the land. 
Kenya and Somalia have separately been moving towards the decentralisation of their political and governance systems. However, the devolved structure is ambiguous about the mandates of the former centralised Government and the new decentralised Federal Government, resulting in lack of clarity about management responsibilities. The TKLBB is under multiple policy governance configurations that influence natural resources management that tend to serve limited interests. However, there is a growing awareness of the need for mutual understanding and enabling livelihoods development, which has gradually incited cross-border interactions through multistakeholder partnerships [63].

To address landscape complexities, ICRAF and partners in 2016 established a multistakeholder platform to serve both sides of the Kenya-Somalia border [63]. The TKLBB Multi-Stakeholder Platform (MSP) is an institutional construct facilitated through the Biodiversity Management Programme (BMP)—an initiative funded by the European Commission through the Intergovernmental Authority on Development (IGAD) of the Horn of Africa. Various stakeholders represent the TKLBB-MSP. These include various local community groups, civil society groups (CSO), non-government organisations (NGOs), and government agencies as well as ministries from Kenya and Somalia, such as Kenya Wildlife Services, Kenya Forestry Department, Somalia Ministry of Environment, and Ministries of Foreign Affairs of Kenya and Somalia. The MSP aims to oversee the establishment of a cross border network of protected areas in the TKLBB land and seascape through sustainable cross border ecosystems management. The IGAD-led BMP's first phase ended in April of 2018, but a second phase started in 2021, focusing on strengthening the TKLBB MSP.

\section{Results and Discussion}

We illustrate polycentric governance as applied in each case study, focusing on the actors' political will, legal framework, support from higher government level, and capacity building. We link the application of these elements with the SDG 16 targets, namely SDG $16.3,16.6$ and 16.7 .

\subsection{SDG 16.3: Promote Rule of Law and Ensure Justice for All}

Law enforcement and justice for all are essential to ensure stakeholders can sustainably manage their natural resources and the environment $[8,10]$. In environmental management, law enforcement and justice relate to the form of precise regulation and the stakeholder's rights and obligations related to resource use $[3,44]$. However, the indicators of SDG 16.3, "Promote rule of law and ensure equal justice for all", narrowly focuses on two aspects: "Underreporting on violence" (16.3.1) and "Number of unsentenced detainees "(16.3.2). We argue that SDG 16.3 indicators should be broadened specifically covering natural resources governance aspects.

In Vietnam, the Payment for Forest Ecosystem Services (PFES) is a landmark policy demonstrating the Government's strong political will to enforce sustainable forest management from national to the local level. PFES is a national policy that obligates water and electricity users to pay upstream forest owners [64]. From an environmental governance perspective, this can be viewed as part of the Government's pursuit to environmental and social justice. Another legal framework is the Land Law, in which the central Government is mandated to ensure local participation in land-use planning. However, in its implementation, the PFES Policy still faces many challenges - it needs to clearly define the roles and responsibilities of local communities and authorities, and other relevant stakeholders (e.g., scientific and development organizations) in the PFES mechanism [65].

Our case study in Na Nhan revealed that local people's involvement in the forest and PFES planning processes has been limited even though participation is required under the PFES and Land use planning laws. Customary rights are not explicitly considered in the local Land and Forest Administration, and commune regulations were mainly derived from national laws rather than based on local situation [60]. It is the duty of commune, district and provincial authorities to enforce law and justice as mandated by the Central Government; however, in terms of forest law enforcement, this is far from being effective 
since the authorities responsible for forest monitoring are limited by lack of capacity and resources to carry out their duties [49].

Our case study also revealed inequity in the PFES benefit distribution, which was seen as a form of social injustice. Payments have been disbursed to almost all households in the village; however, only about $30 \%$ of households participate in forest regeneration activities and much less participate in community forest patrolling, which are the required activities under the PFES scheme [61]. Issues around fairness and justice could be addressed through more deliberative management, in which the local community is closely involved in locallevel planning and management, than merely executing the PFES scheme. Such deliberative governance requires each authority to share and delegate some of the authorities to the other partners to consider multiple point of views in environmental governance, particularly at the local level [66].

To demonstrate how forest law enforcement and justice can be improved in Na Nhan, ICRAF and VAFS researchers, facilitated a participatory integrated land-use planning process that fosters participation and representation at the village level. The process required involvement of village leaders in $\mathrm{Na}$ Nhan commune, and relevant forest stakeholders across governance scales (officials from the commune, district to province). One of the challenges addressed during the planning process, is the mismatch between the planned and actual land-use in Na Nhan, as the official land-use classification from the Government differ from traditional land-use systems associated with local rights, management, and utilisation of forest ecosystem services. To address this conflict, ICRAF researchers conducted land use change analysis, household interviews, and focus group discussions to elicit local understanding and perspectives on forest ecosystems services, and derive local people's land use preferences. The participatory process has resulted in a commune-level land use plan that contains aspects of the National Forest Management Plan, as well as local stakeholders' inputs—-their needs, decisions, and aspirations.

Subsequently, the Commune's Land Use Plan was acknowledged by Na Nhan Commune People's Committee (CPC)-the administrator of the Commune that represents the central Government at the lowest governance level. The PFES scheme will be anchored on the Commune's Land Use Plan; doing so, is expected to improve the equity aspect of the scheme. Through a participatory land use planning process, $\mathrm{Na}$ Nhan's land resources have been allocated to deliver optimum economic and ecological benefits to the local people compared to the previously centralised land-use planning policy [61].

In the cross-border area of Kenya-Somalia, the TKLBB-MSP was established to provide stakeholders at different planning and decision-making levels (village, clans, county, subnational and national) a platform, to level-off understanding about cross-border issues, exchange ideas, share experiences, build trust, and eventually make critical decisions about institutional roles, the rules to be in place, and the solutions to change the desolate situation of people and the landscape $[62,63]$. The MSP was largely supported by external actors, including research organisations and non-government development actors serving as intermediaries between and amongst actors at various levels (ministry-region-countyvillage-clans) and across Kenya and Somalia.

The TKLBB-MSP facilitated various dialogues between and amongst different stakeholders to foster better understanding of natural resources management issues collectively, and clarify their rights and obligations within the landscape [63]. The dialogue processes within and facilitated by the MSP enabled the development not only of rules in safeguarding natural resources, but also livelihoods and development solutions. In addition to facilitating dialogues, MSP members were also given trainings on various topics such as land use planning, biodiversity conservation and livelihoods development-these activities have resulted in the development of site-specific conservation plans, for example, the Community Development Management Plan of the Hanshak Nyongoro community conservancy (77,896 ha) developed in partnership with the Kenya Wildlife Services and the Northern Rangeland Trust (NRT-Coast). 
After long years of unresolved conflict in natural resources management in the TKLBB, law enforcement and efforts to promote justice is slowly coming to life. There is growing willingness for collaboration among actors at different levels-from the ministry level to the local community. High-level support from Kenya and Somalia at the ministry level (Kenya Forestry Department, Somalia Ministry of Environment, and Ministries of Foreign Affairs of Kenya and Somalia) has trickled down to the landscape. The MSP's capacity (the governance actors) and high-level government support are important elements of polycentricity, and have shown promising results in terms addressing long-held conflict in the landscape through local rules and plans for transborder resources management and development.

In Cidanau, the Watershed Forum (FKDC) has promoted environmental law enforcement and social justice through its Integrated Watershed Management (IWRM) and PES Program. The National Regulation No 37/2012 on the Watershed Management mandates sub-national governments to establish a multistakeholder forum in managing the watershed. At the same time, PES is stated in the Environmental Law as an environmental management instrument. As a result, the provincial and district governments have contributed to the IWRM and PES program in Cidanau through the FKDC, such as through funding and allocating development resources [59].

The central government has not provided specific guidelines or regulations for implementing PES and watershed management, but the legal framework mandates promotion of social justice in PES schemes. Efforts to promote justice and fairness within the PES program involve external actors-such as research organisations, universities, and national NGOs that provide capacity building support to FKDC facilitators and members and farmers to implement the PES program. With support from ICRAF, FKDC deployed approaches to foster justice and fairness in the PES program in the form of conservation auctions and participatory project proposal development by farmers group [67].

Active interactions amongst external actors and intensive support from the Rekonvasi Bhumi to FKDC have contributed to achieving justice and rule of law in Cidanau watershed through PES and the IWRM programs. For example, farmers' training on developing a PES proposal helped improve their understanding and awareness of their roles and responsibilities within the PES program, which immensely helped promote understanding between PES participants and non-participants in the village [67]. The polycentric watershed governance in Cidanau presented opportunities to improve law enforcement and promote social justice. This approach aligns with Falk et al. [23] observation that polycentrism can help achieve multiple development objectives in water governance.

While a large part of the discussion about SDG 16.3 focused on how the target would bring peace and security for all $[46,55]$, another issue raised is the need for contextualising actions to ensure justice and law enforcement for the marginalised as an effort to pursue sustainability that could be better represented in SDG $16.3[10,68]$. Our case studies demonstrated the pursuit of justice and law enforcement from the perspective of polycentric environmental governance. In all three cases, interventions to create or improve governance arrangements through different means-land use planning, PES schemes or setting MSPs, have profound effects on enforcing rule of law and achieving social justice, thus contributing to SDG 16.3. However, within the purview of SDG 16.3, these efforts could not be readily aligned to the indicators, which are the 'numbers of violence victims' and "unsentenced detainees".

\subsection{SDG 16.6: Effective, Accountable, and Transparent Institutions at All Levels}

A multi-centre and deliberative governance exemplified in polycentric governance, can help promote effective, accountable institutions at all levels as targeted in SDG 16.6. [69]. However, the target is represented only by two indicators, namely "government expenditure" (16.6.1) and "satisfaction with public services" (16.6.2). This section illustrates how polycentric governance, as adopted in each case study, contributes to achieving "SDG 
16.6-effective, accountable, and transparent institution", but is not explicitly captured in the two SDG 16.6 indicators.

In Vietnam, although a legal framework backs the PFES program, the limited decisionmaking power of local authorities poses a challenge. Despite big statements about devolution and participatory decision-making, much of the authority and power remains at provincial and district government levels - as mentioned above, participation at the village level has been limited [70,71]. Moreover, the monitoring Reporting and Verification (MRV) system is centralised within the forestry sector, contributing to lack of local participation and inhibiting effectiveness and accountability of the PFES program [72]. In some parts of the country, however, some aspects of PFES implementation has been reportedly influenced by local priorities and values [65].

The development of the Commune's Land Use Plan for Multiple Ecosystem Services facilitated by ICRAF and VAFS researchers has shown the critical role of boundary organisations. In polycentric governance, the presence of boundary organisations, such as NGOs, local organisations, and research institutions, is essential in transferring knowledge, experience and ideas; generating feedback, connecting stakeholders across scales, and bridging the gap between actors at different governance levels. Boundary organisations can help address information and power asymmetry, abate potential conflict between local people and government authorities. Researchers from ICRAF and VAFS shifted the centre of decision-making power away from pure political or autocratic control by using the power of evidence-based information (from research), to negotiate consensually agreed decisions. Because of the bridging roles of ICRAF and VAFS, even if the legal framework and willingness of the central Government to actively involve local stakeholders in forest management seemed limited, positive feedback from the CPC of Na Nhan Commune was obtained in support of the Commune's Land Use Plan.

The Na Nhan Commune case study has shown the potential of polycentric governance to bring together Government and non-government actors across scales to collaborate and strengthen local institutions in natural resources and ecosystem services management. Polycentrism, if well combined with pre-existing governance systems (often centralised, monocentric ones), is key in improving effectiveness, accountability, and transparency of governance mechanisms such as PFES [73,74]. Enhancing the diversity of actors and scales involved and decentralising risks and targets will improve the sustainability and effectiveness of the PFES program. To ensure effectiveness of the PFES program, it is vital to build strong local institutions as part of a larger accountable institution that the national PFES policy has created.

In TKLBBL, the MSP's goal was to establish an institutional mechanism for participatory decision-making in line with the broader goal of improving people's livelihoods and the landscape-seascape conditions. The establishment of the MSP indicates a willingness of stakeholders across the Kenya and Somalia border-from the ministries down to the county and village level-to collaborate in managing the landscape better. As a crossborder dialogue platform, the TKLBBL MSP has effectively brought together different types and layers of stakeholders to discuss issues besetting the cross-border landscape. Kenya and Somalia have just been undergoing a decentralisation process, which provided an enabling framework for local development actors to delve into the collaborative management of TKLBB. The decentralised governance that allows local actors to be involved in landscape governance contribute to more effective and accountable management of the cross-border landscape.

Throughout the BMP project, the MSP has received essential support from higher-level governance actors in Kenya and Somalia. National ministries and government agencies from the two countries, including the local Government were involved, and supported the MSP action plans in line with the IGAD-BMP, such as farmers training and facilitation of the local community management and development plan. Another example of the support from higher-level governance for TKLBB was demonstrated by a collaboration between ICRAF, Kenya Wildlife Services (KWS), and the NRT-Coast, sensitising local farmers about 
the 2013 Wildlife Act. As a result, the NRT-Coast developed a community management and development plan and established a community-based monitoring system for Hanshak Nyongoro conservation park.

Through the TKLBB-MSP, local stakeholders' capacity has improved. It demonstrated its effectiveness as a forum to build consensus among various stakeholders across governance scales. In TKLBB, stakeholder engagement through the MSP highlights local level needs and requirements related to institutional capacity and landscape governance. Where long-term conflicts and governance structures have eroded trust, the MSP provided a bridge for building social capital among stakeholders. The MSP has enabled the emergence of leadership in various conservation and development sectors deemed crucial for managing the TKLBB landscape. The coordinating roles of, and the communication process within MSP is expected to support its evolution into an effective and accountable institution to manage the TKLBB landscape.

In Cidanau Watershed, FKDC plays the role of a boundary agent that connects stakeholders across districts within Banten Province. It facilitates and mediates various interests from different administrative boundaries and actors (private companies, Government, and NGOs). To support the PES program and other conservation activities in Cidanau, FKDC collaborates and expands its network with external actors, such as research organisations (ICRAF), NGOs, donors, local and international universities, and relevant national ministries. Thus, FKDC provides an essential role in Cidanau watershed governance, as one of the key factors for successful resource governance is collaboration and connection between stakeholders across landscape scales [27,36]. In Cidanau, the polycentric approach contributes to the social learning process of actors in watershed governance.

In Indonesia's decentralised system, the responsibility for natural resources management is authorised by the national and provincial governments. The Environmental Law and Watershed Regulation provided legal frameworks but did not provide any technical guidelines to implement the PES in the Cidanau watershed. The absence of practical guidelines and examples had made the process of designing and implementing PES and other watershed management programs going through trial-and-error. FKDC utilised its network with external actors to build its members and farmers' capacity to implement the PES scheme and watershed conservation practices.

Mainly based on the references from the Environmental Law No.32/2009 and Watershed Regulations No.37/2012, the Provincial Government officially supported FKDC as a multistakeholder forum through a Governor's Decree. This local legal framework has provided FKDC with the flexibility to request support from the provincial and district Government for its activities, such as co-investment in funding the PES and the development of the Cidanau Watershed Management Program.

The NGO, Rekonvasi Bhumi serves as the managing secretariat of FKDC that helps promote accountability, effectiveness, and transparency in the management of FKDC. For example, it obliged the FKDC to provide the partners with activity reports and to publish its annual financial report in a newspaper. In implementing IWRM and PES in Cidanau, FKDC bridges the actors in Cidanau and provides them with the data and information needed to support decision-making, such as on watershed services values and the watershed service providers and beneficiaries. Such information informs programming and funding allocation for watershed management, particularly from the Government and private companies as the primary water users of Cidanau.

Each of the three case studies has demonstrated efforts to establish transparent and accountable institutions, which is one of the core objectives of SDG 16. In particular, SDG 16.6 indicators denote a priority on solid institutions to contribute to the eradication of state-based corruption $[8,10]$. Institutions in environmental governance often focus on collective action for decision-making and execution of plans, and allocating roles and rules that also cover anti-corruption actions-contributing to SDG 16.6 which emphasise institutions addressing corruption eradication. 
4.3. SDG 16.7:Ensure Responsive, Inclusive, Participatory and Representative Decision-Making at All Levels

In polycentric environmental governance, building the capacity of local institutions is a critically important endeavour, ensuring that decision-making is responsive, inclusive and participative. The two SDG 16.7 indicators are: "Number of positions in public institutions compared to national distributions" (16.7.1) and "Number of populations that believe decision-making is inclusive and responsive" (16.7.2).

With strong State power, Vietnam's governance system is highly centralised. However, as local and customary laws differ significantly from national legislation, state policy enforcement have not always been effective [75]. With due respect to the Vietnamese Government, the legal framework to stimulate local participation and representation in land-use planning and forest management is already in place. The Government also issued a Decree on Forest Protection and Development Fund (FPDF) to capture non-state financial sources to contribute to the national fund for forest management [64]. However, even though the national legal framework is in place, ensuring representation and active participation of local governments and communities in forest governance has been quite a challenge since many actors on the ground lacked the capacity to participate, and are thus, indequately represented [60]. Changes in regulations and resource allocation have not yet reached the desired level that can support decentralized multi-stakeholder forest governance [76].

However, studies on PFES in Vietnam have shown that even though the Central Government predominates the implementation process of PFES, the roles and contribution of non-state actors have already improved significantly since its pilot years in 2009-2010 [65]. As indicated above, a hybrid process has been adopted, in which local interests and values were considered in the implementation of PFES [65]. This indicates the Central Governments' willingness to adopt a more inclusive and representative local decisionmaking process. In the case of Na Nhan, such positive behaviour of the Central Government, was manifested by Commune Officials upon their acknowledgement of the Commune's Land Use Plan. Through the collaborative planning processes, Na Nhan's forest ecosystem services management demonstrates the importance of "cross-scale" governance that were often ignored by the predominant centralised governance practices.

The role of boundary organisations was found essential in decision-making by way of providing technical support in developing the Commune's Land Use Plan. In the process, the village leaders in $\mathrm{Na}$ Nhan Commune actively engaged and shared their perspectives and visions regarding the local land use practices. The villages, albeit not a political or administrative unit under the governance of the Commune, are regarded as local association or group of culturally embedded residents, that contributed greatly to the crafting the Commune's land use plan. Led by a chief or head, the village serves as an important channel for the residents to express their interests to the Government. Local organisations are beneficial, as they often have well-established networks, and are trusted by the local community [72]. Promoting the role and participation of local groups or associations e.g., village, is one of the critical actions to strengthen actors' capacity across levels and increase their representation in forest landscape governance [36].

In TKLBB landscape, distrust between and amongst stakeholders was severe before the initiation of the MSP. The dialogue process that stakeholders went through has helped untangle differences, and gradually, trust emerged through the MSP. Divergent interests exist between different actors at various levels (farm-landscape-region), increasing the complexity of management in TKLBB. To address this complexity and ensure better representation of a range of stakeholders at different levels, ICRAF researchers initiated simple partnerships from the households to the community level, to create "simple coalitions" that advance local issues through the platforms to address broader landscape issues (Figure 2). As shown in Figure 2, there were different decision-making clusters which was started from the household level that formed into community interests groups. Those interests groups 
at the community level would form coalitions that represents household and community interests at the national-regional levels.

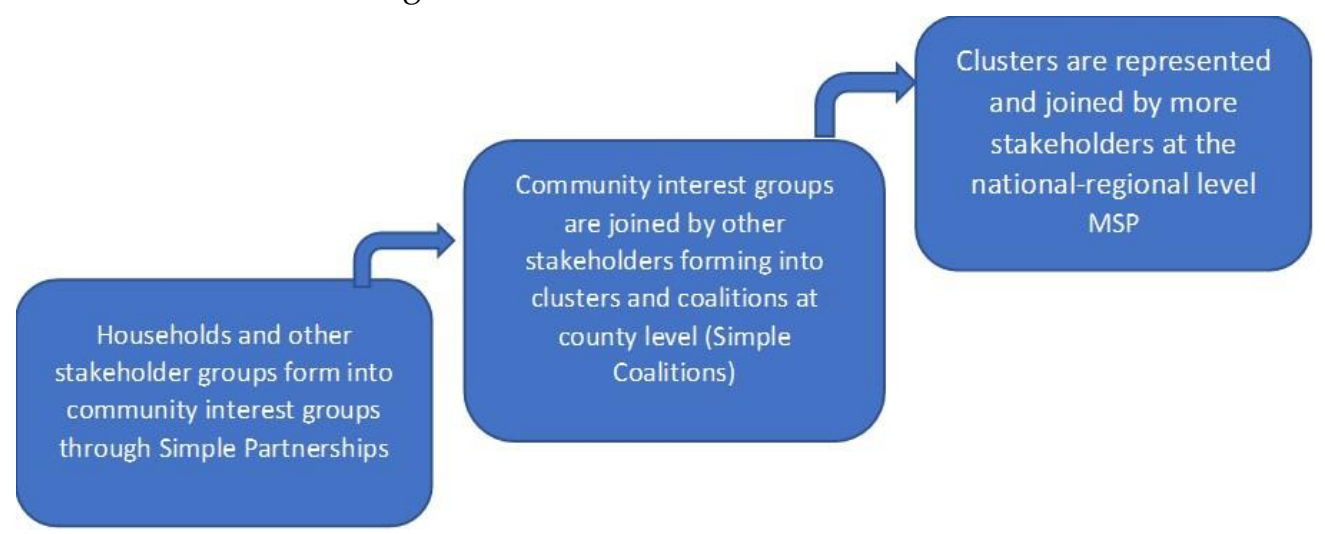

Figure 2. Illustration of coalitions of clusters that make the TKLB MSP.

Through this approach, various decision-making centres involving different actors and authorities at different governance scales were represented and engaged to improve effectiveness, accountability, and transparency in the governance of TKLBB. However, as Baldwin et al. [22] observed in Kenya's Ewaso Ng'iro basin, multiple decision-making centres need to be complemented with regulations and formal conflict mechanisms that incentivise collaboration to strengthen the polycentric governance. In TKLBB, however, such regulations and mechanisms are still at the development stage.

The State Government and Ministries' political will to be involved in the dialogue process, however, contributed to accelerating trust-building. On the Somalia side, the TKLBB-MSP activities were realised through the Ministry of Environment and Tourism of Jubaland state, Ministry of Livestock, Forestry and Range, and the Ministry of Water, Energy, and Minerals of Jubaland state.

The recently implemented decentralised governance in Kenya and Somalia have provided the legal framework for local development actors in the border area to participate more intensively in TKLBB landscape governance. In Kenya, the decentralisation process has been highlighted as the stimulating factor for a polycentric approach to improve water governance, involving multi-scale stakeholders [31,33].

The MSP has served as a consensus-building forum that embrace different representations and viewpoints, nurtured trust between actors across governance scales and transboundary jurisdictions in TKLBB. The MSP has enabled diverse groups in both Kenya and Somalia, which comprised the tribes, clans, sectors, and nationalities, to be well represented in the planning and execution of actions for landscape sustainability and livelihoods. In a conflicted region of TKLBB, the MSP presents opportunities for local stakeholders to look beyond conflict resolution and discuss livelihood improvement opportunities.

In Indonesia, the watershed management regulation mandates the sub-national governments to apply participatory processes that involve all relevant stakeholders in watershed management. Started in the third phase of PES in Cidanau, FKDC applied a participatory process with technical assistance from ICRAF to carry out farmer group selection by submitting proposals to deal with ES buyers' limited resource availability. In this phase, six out of 30 farmer groups with the best proposals were selected for Cidanau's PES contracts [59]. In developing the proposal, the facilitator from FKDC raised farmers' awareness and understanding about PES and helped farmers identify environmental issues, and social and economic needs. The proposal became the input for FKDC to improve the PES scheme design [59].

The proposal development process also revealed village needs that could not be addressed through the PES scheme. In addition, the Governor's Decree provided a legal framework that endorsed FKDC as multi-sectoral government agencies in Cidanau. Responding to local needs, the FKDC would link farmer groups with the relevant government 
offices [59], which also helped to maintain social capital and reduce tension by PES participants and non-participants in Cidanau [77]. Parallel with the proposal selection, farmer groups from the early phase of PES in Cidanau proposed a pay raise, as they have been receiving the same amount for more than ten years. In response, the FKDC facilitated the negotiation with the downstream buyers, and approved the request from these groups.

The Cidanau's case study demonstrates a polycentric governance that is continuously evolving to be inclusive, participative, and responsive to local needs. In such efforts, the national and governor's regulations indicate the availability of enabling legal framework and support from the higher-level Government in Cidanau. The fact that FKDC was being responsive to local needs by negotiating with the farmer groups about the payment, has made inclusivity and participation real in Cidanau. The participatory process also involved capacity building at several scales, from ICRAF to FKDC facilitators, and from FKDC facilitators to farmers groups at the village.

The SDGs 16.6 and 16.7 have strong links to other SDGs [43]. However, critics pointed out that the indicators under SDG 16.7 only focus on state institutions and high-level reporting $[10,55]$. Our case studies, however, demonstrate that participative decisionmaking is needed, and is achievable at the local level. Thus, SDG 16 indicators need to provide indicators that capture the degree to which local level decision-making contributes to responsive and inclusive state-level decision-making.

\section{Conclusions and Recommendation}

Our paper illustrates the potential of a polycentric approach to environmental governance in achieving SDG 16, using case studies from three landscape types: forest, watershed, and transboundary bushland and seascape, in Asia and Africa. The case studies show that polycentric approach in governing the natural resource, landscape, and ecosystem services can be applied, even in the centralized governance setting. By highlighting four key elements of polycentric governance, namely political will, legal framework, support from higher-level governance, and capacity building, the case studies illustrate the role of polycentric governance in achieving three environment-relevant SDG 16 targets: SDG 16.3 "Promote law enforcement and social justice", SDG 16.6 "Effective institutions", and SDG 16.7 "Inclusive, participative, and representative institutions". However, we find that the specific indicators of each of these goals are too restrained, concealing aspects particularly relevant to the environment and natural resource sector.

To harness the natural resource and environment sector's contribution to SDG 16, we present two recommendations. First, foster polycentric environmental governance by providing legal frameworks that permit power-sharing and participatory decisionmaking, building strong local institutions, and nurturing participation. Second, incorporate environmental governance targets in SDG 16, to highlight the eminent aspect of "rule of law, social justice, and institutions" in natural resources management, and strengthen the sector's contributions in achieving SDG 16. Over the course of history, natural resource contestation coupled with weak institutions at multiple scales (local, sub-national, national) have resulted in many contemporary environmental problems. Exacerbated by climate change, conflict, injustice, and unsustainable development will persist if the space remains blurry for the environment sector within the SDG-16.

Author Contributions: Conceptualization of this paper was by D.C., B.L. and S.A.; methodology, formal analysis, information/data curation, validation by S.A., D.T.H. and D.C.; writing-original draft preparation by S.A., D.T.H., D.C. and B.L.; writing-review and editing by S.A., D.T.H., D.C., B.L. and M.M.; supervision by D.C.; project administration by D.C. All authors have read and agreed to the published version of the manuscript.

Funding: This research was funded by "Policies, Institutions, and Markets" (PIM), a CGIAR Research program coordinated by the International Food Policy Research Institute (IFPRI).

Institutional Review Board Statement: Not applicable.

Informed Consent Statement: Not applicable. 
Data Availability Statement: Not applicable.

Acknowledgments: The authors gratefully acknowledge the CGIAR Research Program "Policies, Institutions, and Markets" coordinated by IFPRI for its funding, administrative, technical and coordination support in the conduct of the study. Special thanks to NP Rahadian from FKDC for the comments provided to the manuscript.

Conflicts of Interest: The authors declare no conflict of interest with any institutions or persons in the preparation and representation of this manuscript.

\section{References}

1. Washington, H. Demystifying Sustainability: Towards Real Solutions; Routledge: London, UK, 2015.

2. Sarmidi, T.; Hook Law, S.; Jafari, Y. Resource Curse: New Evidence on the Role of Institutions. Int. Econ. J. 2014, 28, 191-206. [CrossRef]

3. Weir, D. What the Absence of the Environment in Sdg 16 on Peace and Security Should Tell Us; CEOBS: West Yorkshire, UK, 2016. Available online: https: / ceobs.org/what-the-absence-of-the-environment-in-sdg16-on-peace-and-security-should-tell-us / (accessed on 14 December 2020).

4. Mehlum, H.; Moene, K.; Torvik, R. Institutions and the resource curse. Econ. J. 2006, 116, 1-20. [CrossRef]

5. Hope Sr, K.R. Peace, justice and inclusive institutions: Overcoming challenges to the implementation of Sustainable Development Goal 16. Glob. Change Peace Secur. 2020, 32, 57-77. [CrossRef]

6. UNEP. SDG 16. In Issue Brief; UNEP: Nairobi, Kenya, 2019.

7. Dohlman, E. Policy Coherence for Sustainable Development in the Post-2015 Framework. In Proceedings of the UN Expert Group Meeting, New York, NY, USA, 4-5 December 2014. Available online: https:/ /www.un.org/en/ecosoc/egm/pdf/presentation_ session_iii_dohlman.pdf (accessed on 14 December 2020).

8. Menton, M.; Larrea, C.; Latorre, S.; Martinez-Alier, J.; Peck, M.; Temper, L.; Walter, M. Environmental justice and the SDGs: From synergies to gaps and contradictions. Sustain. Sci. 2020, 15, 1-16. [CrossRef]

9. WRI. Sustainable Development Goal 16. Available online: https://www.wri.org/sdg-16 (accessed on 21 November 2020).

10. McDermott, C.L.; Acheampong, E.; Arora-Jonsson, S.; Asare, R.; de Jong, W.; Hirons, M.; Khatun, K.; Menton, M.; Nunan, F.; Poudyal, M.; et al. SDG 16: Peace, justice and strong institutions-a political ecology perspective. In Sustainable Development Goals: Their Impacts on Forests and People; Katila, P., Colfer, C.J.P., de Jong, W., Galloway, G., Pacheco, P., Winkel, G., Eds.; Cambridge University Press: Cambridge, UK, 2019; pp. 510-540. [CrossRef]

11. Cole, D.H. Advantages of a polycentric approach to climate change policy. Nat. Clim. Change 2015, 5, 114. [CrossRef]

12. Görg, C. Landscape governance: The "politics of scale" and the "natural" conditions of places. Geoforum 2007, 38, 954-966. [CrossRef]

13. Huitema, D.; Mostert, E.; Egas, W.; Moellenkamp, S.; Pahl-Wostl, C.; Yalcin, R. Adaptive water governance: Assessing the institutional prescriptions of adaptive (co-) management from a governance perspective and defining a research agenda. Ecol. Soc. 2009, 14, 26. [CrossRef]

14. Ostrom, E. Beyond markets and states: Polycentric governance of complex economic systems. Am. Econ. Rev. 2010, 100, 641-672. [CrossRef]

15. Goegele, H. Towards a polycentric approach to implement the 2030 Agenda. In Proceedings of the Workshop on the Ostrom Workshop 6, Indiana University, Bloomington, IN, USA, 19-21 June 2019.

16. Ostrom, E. Polycentric systems for coping with collective action and global environmental change. Glob. Environ. Change 2010, 20, 550-557. [CrossRef]

17. Molle, F.; Mamanpoush, A. Scale, governance and the management of river basins: A case study from Central Iran. Geoforum 2012, 43, 285-294. [CrossRef]

18. Termeer, C.J.A.M.; Dewulf, A.; van Lieshout, M. Disentangling scale approaches in governance research: Comparing monocentric, multilevel, and adaptive governance. Ecol. Soc. 2010, 15, 29.

19. Ostrom, E. Coping with tragedies of the commons. Annu. Rev. Political Sci. 1999, 2, 493-535. [CrossRef]

20. Andersson, K.P.; Ostrom, E. Analyzing decentralized resource regimes from a polycentric perspective. Policy Sci. 2008, 41, 71-93. [CrossRef]

21. Nagendra, H.; Ostrom, E. Polycentric governance of multifunctional forested landscapes. Int. J. Commons 2012, 6 , 104-133. [CrossRef]

22. Baldwin, E.; McCord, P.; Dell'Angelo, J.; Evans, T. Collective action in a polycentric water governance system. Environ. Policy Gov. 2018, 28, 212-222. [CrossRef]

23. Falk, T.; Bock, B.; Kirk, M. Polycentrism and poverty: Experiences of rural water supply reform in Namibia. Water Altern. 2009, 2,115 .

24. Lankford, B.; Hepworth, N. The cathedral and the bazaar: Monocentric and polycentric river basin management. Water Altern. $2010,3,82$. 
25. Rist, S.; Chidambaranathan, M.; Escobar, C.; Wiesmann, U.; Zimmermann, A. Moving from sustainable management to sustainable governance of natural resources: The role of social learning processes in rural India, Bolivia and Mali. J. Rural Stud. 2007, 23, 23-37. [CrossRef]

26. Carlisle, K.; Gruby, R.L. Polycentric systems of governance: A theoretical model for the commons. Policy Stud. J. 2019, 47, 927-952. [CrossRef]

27. Bruns, B. Challenges of Polycentric Water Governance in Southeast Asia: Awkward Facts, Missing Mechanisms, and Working with Institutional Diversity. In Redefining Diversity E Dynamics of Natural Resources Management in Asia; Chapter 4; Ganesh, P.S., Ujjwal, P., Helmi, Eds.; Elsevier: Amsterdam, The Netherlands, 2017; Volume 1, pp. 55-66. [CrossRef]

28. Leimona, B.; van Noordwijk, M.; de Groot, R.; Leemans, R. Fairly efficient, efficiently fair: Lessons from designing and testing payment schemes for ecosystem services in Asia. Ecosyst. Serv. 2015, 12, 16-28. [CrossRef]

29. Abers, R.N. Organizing for Governance: Building Collaboration in Brazilian River Basins. World Dev. 2007, 35, 1450-1463. [CrossRef]

30. Gelcich, S. Towards polycentric governance of small-scale fisheries: Insights from the new 'Management Plans' policy in Chile. Aquat. Conserv. Mar. Freshw. Ecosyst. 2014, 24, 575-581. [CrossRef]

31. Baldwin, E.; Washington-Ottombre, C.; Dell'Angelo, J.; Cole, D.; Evans, T. Polycentric Governance and Irrigation Reform in Kenya. Governance 2016, 29, 207-225. [CrossRef]

32. Lalika, M.C.S.; Meire, P.; Ngaga, Y.M. Exploring watershed conservation and water governance along Pangani River Basin, Tanzania. Land Use Policy 2015, 48, 351-361. [CrossRef]

33. McCord, P.; Dell'Angelo, J.; Baldwin, E.; Evans, T. Polycentric Transformation in Kenyan Water Governance: A Dynamic Analysis of Institutional and Social-Ecological Change. Policy Stud. J. 2017, 45, 633-658. [CrossRef]

34. Bushley, B.R. REDD+ policy making in Nepal: Toward state-centric, polycentric, or market-oriented governance? Ecol. Soc. 2014, 19. [CrossRef]

35. Long, H.; Liu, J.; Tu, C.; Fu, Y. From State-controlled to Polycentric Governance in Forest Landscape Restoration: The Case of the Ecological Forest Purchase Program in Yong'an Municipality of China. Environ. Manag. 2018, 62, 58-69. [CrossRef]

36. Riggs, R.; Langston, J.; Margules, C.; Boedhihartono, A.; Lim, H.; Sari, D.; Sururi, Y.; Sayer, J. Governance Challenges in an Eastern Indonesian Forest Landscape. Sustainability 2018, 10, 169. [CrossRef]

37. Caron, C.; Fenner, S. Forest Access and Polycentric Governance in Zambia's Eastern Province: Insights for REDD. Int. For. Rev. 2017, 19, 265-277. [CrossRef]

38. Pedersen, R.H. Access to land reconsidered: The land grab, polycentric governance and Tanzania's new wave land reform. Geoforum 2016, 72, 104-113. [CrossRef]

39. Ros-Tonen, M.; Derkyi, M.; Insaidoo, T. From co-management to landscape governance: Whither Ghana's modified taungya system? Forests 2014, 5, 2996-3021. [CrossRef]

40. Falk, T.; Spangenberg, J.H.; Siegmund-Schultze, M.; Kobbe, S.; Feike, T.; Kuebler, D.; Settele, J.; Vorlaufer, T. Identifying governance challenges in ecosystem services management-Conceptual considerations and comparison of global forest cases. Ecosyst. Serv. 2018, 32, 193-203. [CrossRef]

41. Metzger, J.P.; Fidelman, P.; Sattler, C.; Schröter, B.; Maron, M.; Eigenbrod, F.; Fortin, M.-J.; Hohlenwerger, C.; Rhodes, J.R. Connecting governance interventions to ecosystem services provision: A social-ecological network approach. People Nat. 2021, 3, 266-280. [CrossRef]

42. Ivanovic, A.; Cooper, H.; Nguyen, A.M. Institutionalisation of SDG 16: More a trickle than a cascade? Soc. Altern. 2018, 37, 49-57.

43. Whaites, A. Achieving the Impossible: Can We Be SDG 16 Believers? GovNet Background Paper. 2016, 2, 14.

44. Elder, M.; Olsen, S.H. The Design of Environmental Priorities in the SDG s. Glob. Policy 2019, 10, 70-82. [CrossRef]

45. Amaruzaman, S.; Bardsley, K.D.; Stringer, R. Reflexive Policies and the Complex Socio-ecological Systems of the Upland Landscapes in Indonesia. Agric. Hum. Values 2022. In Press.

46. UNDP. Monitoring the Implementation of SDG 16 for Peaceful, Just and Inclusive Societies: Pilot Initiative on National-Level Monitoring of SDG 16; UNDP: Oslo, Norway, 2017; 37p. Available online: file:/ / C:/Users/MDPI/AppData/Local/Temp/Monitoring\%20to\% 20Implement\%20SDG16_Pilot\%20Initiative.pdf (accessed on 14 December 2021).

47. UNEP. GOAL 16: Peace, Justice and Strong Institutions. Available online: https://www.unenvironment.org/explore-topics/ sustainable-development-goals / why-do-sustainable-development-goals-matter/goal-16 (accessed on 6 July 2020).

48. Meuleman, L.; Niestroy, I. Common but differentiated governance: A metagovernance approach to make the SDGs work. Sustainability 2015, 7, 12295-12321. [CrossRef]

49. Lemos, M.C.; Agrawal, A. Environmental Governance. Annu. Rev. Environ. Resour. 2006, 31, 297-325. [CrossRef]

50. Winkler, K.J.; Garcia Rodrigues, J.; Albrecht, E.; Crockett, E.T.H. Governance of ecosystem services: A review of empirical literature. Ecosyst. People 2021, 17, 306-319. [CrossRef]

51. Bodin, Ö. Collaborative environmental governance: Achieving collective action in social-ecological systems. Science 2017, 357, eaan1114. [CrossRef]

52. Frantzeskaki, N. Seven lessons for planning nature-based solutions in cities. Environ. Sci. Policy 2019, 93, 101-111. [CrossRef]

53. Schoon, M. Governance in transboundary conservation: How institutional structure and path dependence matter. Conserv. Soc. 2013, 11, 420-428. [CrossRef]

54. Chen, S.; Pernetta, J.C.; Duda, A.M. Towards a new paradigm for transboundary water governance: Implementing regional frameworks through local actions. Ocean Coast. Manag. 2013, 85, 244-256. [CrossRef] 
55. Jandl, M. Towards the monitoring of Goal 16 of the United Nations' sustainable development goals (SDGs). In UN Sabbatical Leave Research Report; UN: Helshinki, Finland, 2017; 100p. Available online: https:/ /hr.un.org/sites/hr.un.org/files/editors/u604 /Towards\%20the\%20monitoring\%20of\%20Goal\%2016\%20of\%20ther\%20SDG.pdf (accessed on 14 December 2021).

56. Pahl-Wostl, C.; Knieper, C. The capacity of water governance to deal with the climate change adaptation challenge: Using fuzzy set Qualitative Comparative Analysis to distinguish between polycentric, fragmented and centralized regimes. Glob. Environ. Change 2014, 29, 139-154. [CrossRef]

57. Buytaert, W.; Dewulf, A.; Bièvre, B.D.; Clark, J.; Hannah, D.M. Citizen Science for Water Resources Management: Toward Polycentric Monitoring and Governance? J. Water Resour. Plan. Manag. 2016, 142, 155-169. [CrossRef]

58. Bixler, R.P. From Community Forest Management to Polycentric Governance: Assessing Evidence from the Bottom Up. Soc. Nat. Resour. 2014, 27, 155-169. [CrossRef]

59. Amaruzaman, S.; Rahadian, N.; Leimona, B. Role of intermediaries in the Payment for Environmental Services scheme: Lessons learnt in the Cidanau watershed, Indonesia. In Co-Investment in Ecosystem Services: Global Lessons from Payment and Incentive Schemes; World Agroforestry Centre (ICRAF): Nairobi, Kenya, 2017.

60. Do, T.H.; Nguyen, V.T.; Vu, T.P. Landscape Tree Cover Transition, Drivers and Stakeholder Perspectives-A Case Study in Na Nhan commune, Dien Bien Province, Vietnam; World Agroforestry Centre: Hanoi, Vietnam, 2017; 30p.

61. Do, T.H.; Vu, T.P.; Catacutan, D. Governing Landscapes for Ecosystem Services: A Participatory Land-Use Scenario Development in the Northwest Montane Region of Vietnam. Environ. Manag. 2020, 1-18. [CrossRef]

62. Tanui; Catacutan, D.C. TKLBBs Cross-Border MSP-A Case Study; IFPRI: Nairobi, Kenya, 2020.

63. Tanui, J.; Koech, G.; Catacutan, D.C. Governing a Shared, Critical Biodiversity Landscape through Cross-Border Dialogue Platform; World Agroforestry Centre (ICRAF): Nairobi, Kenya, 2018.

64. Pham, T.T.; Bennett, K.; Vu, T.P.; Brunner, J.; Le Ngoc, D.; Nguyen, D.T. Payments for Forest Environmental Services in Vietnam: From Policy to Practice; CIFOR: Ha Noi, Vietnam, 2013.

65. McElwee, P.; Huber, B.; Nguyễn, T.H.V. Hybrid outcomes of payments for ecosystem services policies in Vietnam: Between theory and practice. Dev. Change 2020, 51, 253-280. [CrossRef]

66. Neef, A. Transforming rural water governance: Towards deliberative and polycentric models? Water Altern. $2009,2,53$.

67. McGrath, F.L.; Leimona, B.; Amaruzaman, S.; Rahadian, N.P.; Carrasco, L.R. Identifying payments for ecosystem services participants through social or spatial targeting? Exploring the outcomes of group level contracts. Conserv. Sci. Pract. 2019, 1, e49. [CrossRef]

68. Satterthwaite, M.L.; Dhital, S. Measuring access to justice: Transformation and technicality in SDG 16.3. Glob. Policy 2019, 10, 96-109. [CrossRef]

69. Visseren-Hamakers, I.J. Integrative environmental governance: Enhancing governance in the era of synergies. Curr. Opin. Environ. Sustain. 2015, 14, 136-143. [CrossRef]

70. Do, T.H.; Vu, T.P.; Nguyen, V.T.; Catacutan, D. Payment for forest environmental services in Vietnam: An analysis of buyers perspectives and willingness. Ecosyst. Serv. 2018, 32, 134-143. [CrossRef]

71. Libert-Amico, A.; Larson, A.M. Forestry Decentralization in the Context of Global Carbon Priorities: New Challenges for Subnational Governments. Front. For. Glob. Change 2020, 3, 15. [CrossRef]

72. Pham, T.T.; Moeliono, M.; Brockhaus, M.; Le, D.N.; Wong, G.Y.; Le, T.M. Local preferences and strategies for effective, efficient, and equitable distribution of PES revenues in Vietnam: Lessons for REDD+. Hum. Ecol. 2014, 42, 885-899. [CrossRef]

73. Moeliono, M.; Pham, T.T.; Le, N.D.; Brockhaus, M.; Wong, G.; Kallio, M.; Nguyen, D.T. Local governance, social networks and REDD+: Lessons from swidden communities in Vietnam. Hum. Ecol. 2016, 44, 435-448. [CrossRef]

74. Sunderlin, W.D.; Sills, E.; Duchelle, A.E.; Ekaputri, A.; Kweka, D.; Toniolo, M.; Ball, S.; Doggart, N.; Pratama, C.; Padilla, J. REDD+ at a critical juncture: Assessing the limits of polycentric governance for achieving climate change mitigation. Int. For. Rev. 2015, 17, 400-413. [CrossRef]

75. Sikor, T. The allocation of forestry land in Vietnam: Did it cause the expansion of forests in the northwest? For. Policy Econ. 2001, 2,1-11. [CrossRef]

76. Dang, T.K.P.; Van Der Zouwen, M.; Arts, B. Challenges of forest governance: The case of forest rehabilitation in Vietnam. Public Organ. Rev. 2019, 19, 425-452. [CrossRef]

77. McGrath, F.; Erbaugh, J.T.; Leimona, B.; Amaruzaman, S.; Rahadian, N.P.; Carrasco, L. Green without envy: How social capital alleviates tensions from a Payments for Ecosystem Services (PES) program in Indonesia. Ecol. Soc. 2018, 23, 10. [CrossRef] 